\title{
Pelatihan dan Pendampingan Penyusunan Laporan Harga Pokok Produksi pada Badan Usaha Milik Desa di Desa Kerinjing, Kabupaten Ogan Ilir
}

\author{
Yusnaini $^{1 *}$, Kencana Dewi ${ }^{1}$, Burhanudin $^{1}$, Arista Hakiki $^{1}$, dan Eka Meirawati ${ }^{1}$ \\ ${ }^{1}$ Fakultas Ekonomi, Universitas Sriwijaya, Sumatera Selatan, Indonesia \\ *Email korespondensi: yusnaini@fe.unsri.ac.id
}

Info Artikel: Diterima: 22 Agustus 2020; Disetujui: 25 September 2020; Dipublikasi: 16 Oktober 2020

\begin{abstract}
Abstrak: Kegiatan Pengabdian Kepada Masyarakat ini bertujuan untuk memberikan pendampingan kepada Badan Usaha Milik Desa di desa Kerinjing agar mampu menghitung Harga Pokok Produksi sebagai dasar penentuan Harga Jual Produk. Adapun metode kegiatan ini dilakukan dengan memberikan penyuluhan dan sekaligus pendampingan secara langsung kepada badan usaha milik desa di desa Kerinjing, Ogan Ilir. Hasil pengabdian masyarakat ini ditandai dengan antusias dan kemampuan peserta dalam menerima materi dan mampu melakukan praktek untuk menghitung biaya produksi, harga pokok produksi dan harga pokok penjualan serta harga pokok masing-masing produk sebagai dasar penentuan harga jual, hasil kegiatan ini sangat bermanfaat bagi badan usaha milik desa di desa Kerinjing, Ogan Ilir.
\end{abstract}

Keywords: Biaya Produksi; Harga Pokok Produksi; Harga Pokok; Harga Jual.

Kutipan:

Yusnaini, Y., Dewi, K., Burhanudin, B., Hakiki, A., \& Meirawati, E. (2020). Pelatihan dan Pendampingan Penyusunan Laporan Harga Pokok Produksi pada Badan Usaha Milik Desa di Desa Kerinjing. Sricommerce: Journal of Sriwijaya Community Services, 1(2): 63-68. DOI: https://doi.org/10.29259/jscs.v1i2.22

\section{PENDAHULUAN}

Untuk mencapai tujuan pembangunan nasional, desa merupakan agen pemerintah terdepan yang dapat menjangkau kelompok sasaran riil yang hendak disejahterakan, yaitu dengan membentuk suatu badan usaha yaitu Badan Usaha Milik Desa yang sesuai dengan permendagri nomor 39 tahun 2010 tentang badan usaha milik desa. Badan usaha milik desa ini usaha desa yang dibentuk/didirikan oleh pemerintah desa yang kepemilikan modal dan pengelolaannya dilakukan oleh pemerintah desa dan masyarakat.

Pembentukan badan usaha milik desa ini juga berdasarkan pada Permendagri nomor 39 tahun 2010 pada bab II tentang pembentukan badan usaha milik desa. Pembentukan ini berasal dari pemerintah kabupaten/kota dengan menetapkan peraturan daerah tentang pedoman tata cara pembentukan dan pengelolaan bumdes. Selanjutnya pemerintah desa membentuk bumdes dengan peraturan desa yang berpedoman pada peraturan daerah. Peraturan daerah tersebut akan muncul dengan adanya Undang-undang nomor 12 tahun 2008 perubahan atas Undang-undang nomor 32 tahun 2004 tentang pemerintahan daerah. Cara kerja BUMDes adalah menampung kegiatan-kegiatan ekonomi masyarakat dalam sebuah bentuk kelembagaan atau badan usaha yang dikelola secara profesional, namun tetap bersandar pada potensi asli desa, sehingga dapat menjadikan usaha masyarakat lebih produktif dan efektif.

Permasalahan yang dihadapi dalam proses produksi badan usaha milik desa antara lain 
adalah penentuan harga pokok produksi yang akurat. Banyak Badan Usaha Milik Desa yang kurang memperhatikan bagaimana menentukan biaya produksi yang tepat untuk produk mereka. Hal ini dikarenakan kurangnya pengetahuan mengenai jenis-jenis biaya dan bagaimana memposisikan biaya dalam penentuan harga pokok. Fokus permasalahan yang dihadapi pada BUMDes adalah bagaimana menentukan harga pokok produksi dengan tepat. Dengan demikian permasalahan yang dihadapi antara lain adalah kesiapan pemahaman sumberdaya manusia, pembukuan yang diperlukan, dokumentasi atau formulir yang mendukung proses penyusunan laporan harga pokok produksi badan usaha milik desa.

Kabupaten Ogan Ilir merupakan salah satu kabupaten di Provinsi Sumatera Selatan dimana Universitas Sriwijaya berada pada daerah ini. Kabupaten Ogan ilir memiliki 16 kecamatan, diantaranya kecamatan Tanjung Raja dengan luas 70,41 km2, yang memiliki 19 desa, 52 dusun dan 140 RT dan jumlah penduduk pada tahun 2015 sebanyak 43.814 jiwa. Diantara desa di kecamatan tersebut terdapat desa Kerinjing, memiliki jumlah penduduk pada akhir tahun 2015 sebanyak 1.279 jiwa, terdiri dari 647 laki-laki dan 632 perempuan dan jumlah rumah tangga sebanyak 336 Rumah Tangga (Budiman, et al., 2020).

Masyakarat Desa Kerinjing kabupaten Ogan Ilir, hampir 100 persen beragama Islam. Desa ini dipimpin oleh kepala Desa bernama Usman Umar, memiliki wilayah 4 RT dan 2 Dusun. Potensi yang ada didesa Kerinjing tidaklah cukup banyak tetapi mudah-mudahan dengan sentuhan bantuan dari pihak yang terkait, potensi desa tersebut dapat dikembangkan terutama dibidang pertanian dan perkebunan. Sebanyak $49 \%$ penduduk desa berpendapatan dari hasil pertanian dan perkebunan, lahan persawahan dengan luas $\pm 84 \mathrm{Ha}$ dan lahan perkebunan seluas $\pm 105 \mathrm{Ha}$ yang dapat dijadikan aspirasi pemerintah untuk membantu para petani dalam meningkatkan produktifitas hasil pertanian dengan didukung sarana dan prasarana yang memadai. Potensi didesa dibidang kesehatan seperti POSKESDES, POSYANDU dan BIDES, dari potensi ini memang sangatlah dibutuhkan masyarakat yang maju menuju Ogan Ilir sehat. Dari bidang ekonomi potensi desa juga dapat diliha dari usaha-usaha keluarga seperti pembuatan pakaian (penjahit), usaha angkutan umum, warung-warung sembako, sedangkan potensi dibidang sarana dan prasarana seperti jalan desa yang cukup panjang, sarana pendidikan. Potensi perikanan yang ada didesa Kerinjing cuma nelayan penangkap ikan sawah liar dan sebagian membudidayakan ikan air tawar, dibidang SDM masih banyak SDM yang terampil tetapi tidak bisa menggunakan keahliannya pada umum karena tidak didukung dengan pendidikan keterampilan yang memadai dan persaingan kerja yang banyak.

Pelatihan dan pendampingan penyusunan laporan harga pokok produksi pada desa Kerinjing di rasa perlu karena selama ini harga jual produk yang dihasilkan oleh Bumdes di desa tersebut belum didasarkan pada nilai harga pokok yang akurat. Dengan demikian diharapkan setelah adalah pemahaman mengenai penentuan harga pokok yang tepat dapat ditentukan nilai jual yang relevan terhadap produk. Penentuan harga jual produl yang tepat diharapkan dapat meningkatkan penjualan produk produk yang dihasilkan Bumdes Desa Kerinjing. Dengan pemahaman atas penentuan harga pokok produk tersebut pada akhirnya dapat mencapai tujuan pendirian Bumdes yaitu meningkatkan perekonomian desa, meningkatkan pendapatan asli desa, meningkatkan pengolahan potensi desa sesuai kebutuhan masyarakat, dan menjadi tulang punggung pertumbuhan dan pemerataan ekonomi pedesaan. Peserta dalam kegiatan pengabdian kepada masyarakat di desa Kerinjing ini berjumlah \pm 30 orang. Materi yang disampaikan adalah materi yang berhubungan dengan biaya produksi, harga pokok produksi, beban pokok penjualan, harga pokok produk dan harga jual agar masyarakat yang menjadi peserta dapat menerima materi tersebut dengan baik dan tepat sasaran sesuai dengan tujuan kegiatan pengabdian yang telah ditentukan sebelumnya.

\section{STUDI PUSTAKA}

\subsection{Pengertian Biaya}

Menurut Carter (2009:30) biaya adalah sebagai suatu nilai tukar, pengeluaran, atau pengorbanan yang dilakukan untuk menjamin perolehan manfaat. Sedangkan menurut Mulyadi 
(2007) definisi biaya dibagi atas dua yaitu biaya dalam arti luas dan biaya dalam arti sempit. Dalam arti luas biaya merupakan pengorbanan sumber ekonomi yang diukur dalam satuan uang yang telah terjadi dan kemungkinan akan terjadi untuk tujuan tertentu. Sedangkan dalam arti sempit, biaya diartikan sebagai pengorbanan sumber ekonomi untuk memperoleh aktiva. Dari uraian di atas dapat ditarik kesimpulan bahwa biaya adalah pengorbanan sumber daya ekonomi untuk mencapai tujuan tertentu yang dapat memberikan manfaat bagi perusahaan baik saat ini maupun di masa yang akan datang.

\subsection{Jenis-jenis Biaya}

Dalam akuntansi biaya, biaya dapat dikelompokkan dalam berbagai macam cara. Umumnya klasifikasi biaya ini ditentukan atas dasar tujuan yang hendak dicapai dengan penggolongan tersebut. Penggolongan biaya dapat dilakukan berdasarkan :

1. Biaya Berdasarkan Objek Pengeluaran

Dalam cara ini, nama objek pengeluaran merupakan dasar penggolongan biaya. Contoh : biaya yang dikeluarkan untuk bahan bakar disebut dengan biaya bahan bakar.

2. Biaya Berdasarkan Fungsi Pokok Dalam Perusahaan.

a. Biaya Produksi merupakan biaya yang terjadi untuk mengolah bahan baku menjadi produk jadi yang siap untuk dijual.

b. Biaya Pemasaran merupakan biaya yang terjadi untuk melaksanakan pemasaran produk.

c. Biaya Administrasi dan Umum merupakan biaya-biaya yang dikeluarkan untuk mengkoordinasi kegiatan produksi dan pemasaran produk.

3. Biaya Berdasarkan Hubungan Biaya Dengan Suatu Yang Dibiayai

a. Biaya Langsung adalah biaya yang terjadi, yang penyebab satu-satunya adalah karena adanya sesuatu yang dibiayai. Biaya langsung ini akan lebih mudah diidentifikasi.

b. Biaya Tidak Langsung adalah niaya yang terjadi tidak hanya disebabkan oleh sesuatu yang dibiayai. Biaya tidak langsung tidak mudah diidentifikasi dengan produk tertentu.

4. Biaya Berdasarkan Perilaku Biaya dalam Hubungannya Dengan Perubahan Volume Kegiatan

a. Biaya Variabel adalah biaya yang totalnya berubah sebanding perubahan volume kegiatan.

b. Biaya Semi Variabel adalah biaya yang berubah tidak sebanding dengan perubahan volume kegiatan.

c. Biaya Semifixed adalah biaya yang tetap untuk tingkat volume kegiatan tertentu dan berubah dengan jumlah yang konstan pada volume produksi tertentu.

d. Biaya Tetap adalah biaya yang totalnya tetap dalam kisaran volume kegiatan tertentu.

5. Biaya Berdasarkan Jangka Waktu Manfaatnya

a. Pengeluaran modal adalah biaya yang mempunyai manfaat lebih dari suatu periode akuntansi.

b. Pengeluaran Pendapatan adalah biaya yang hanya mempunyai manfaat dalam periode akuntansi terjadinya pengeluaran tersebut.

\subsection{Biaya Produksi}

Mulyadi (2010) menyatakan bahwa biaya produksi merupakan biaya-biaya yang dikeluarkan dalam pengelolaan bahan baku menjadi produk. Biaya produksi membentuk kos produksi, yang digunakan untuk menghitung cost produk jadi dan cost produk yang pada akhir periode akuntansi masih dalam proses. Pengumpulan cost produksi sangat ditentukan oleh cara produksi. Secara garis besar, cara memproduksi produk dapat dibagi menjadi dua macam, yaitu : produksi atas dasar pesanan dan produksi massa atau proses. Perusahaan yang berproduksi berdasarkan pesanan melaksanakan pengelolaan produknya atas dasar pesanan yang diterima dari pihak luar. Contoh perusahaan yang berproduksi berdasarkan pesanan antara lain adalah perusahaan percetakan, perusahaan mebel, perusahaan dok kapal. Perusahaan yang berproduksi berdasarkan produk massa melaksanakan pengolahan produksinya untuk memenuhi persediaan digudang. Umumnya produknya berupa produk standar. Contoh perusahaan yang berproduksi massa antara lain adalah perusahaan semen, pupuk, makanan ternak, bumbu masakan, makanan ringan dan tekstil. 


\subsection{Perhitungan Harga Pokok Produksi}

Apa yang dimaksud dengan biaya produksi (production cost)? Pengertian biaya produksi adalah total biaya yang dikeluarkan oleh suatu perusahaan dalam proses produksi yang bertujuan untuk menghasilkan suatu barang atau produk yang siap dipasarkan.Ada juga yang menyebutkan pengertian biaya produksi adalah akumulasi biaya yang diperlukan dalam proses produksi, mencakup biaya bahan baku, biaya tenaga kerja langsung, dan biaya overhead pabrik. Production cost akan membentuk harga pokok produksi yang nantinya dipakai untuk menghitung harga pokok barang jadi dan harga pokok barang pada saat akhir periode akuntansi masih berlangsung. Menurut Charles T. Horngren, unsur-unsur biaya produksi terdiri dari, pertama biaya bahan baku langsung yang merupakan bahan yang secara langsung dipakai untuk memproduksi suatu barang jadi yang siap dipasarkan. Bahan baku tersebut mencakup semua bahan yang secara fisik dapat diidentifikasi sebagai bagian dari produk jadi. Kedua adalah biaya tenaga kerja langsung yang merupakan biaya-biaya bagi semua tenaga kerja langsung yang ditempatkan dan diberdayakan dalam menangani kegiatan produksi secara langsung. Ketiga adalah biaya overhead pabrik yang merupakan semua biaya manufaktur yang tidak ditelusuri secara langsung ke output tertentu. Beberapa elemen biaya overhead pabrik diantaranya; biaya bahan baku tidak langsung, biaya tenaga kerja tidak langsung, biaya depresiasi dan amortisasi aktiva tetap, biaya reparasi dan pemeliharaan mesin, biaya listrik dan air pabrik, biaya asuransi pabrik dan biaya overhead lain-lain.

\section{METODE}

Pelaksanaan pengabdian masyarakat di Desa Kerinjing kecamatan Tanjung Raja di Ogan Ilir, Sumatera Selatan adalah hari Kamis, 14 November 2019. Metode pelaksanaan pengabdian yang akan dilakukan dengan menggunakan metode ceramah, tutorial dan diskusi. Adapun sistematika pelaksanaan kegiatan pengabdian ini dengan menggunakan metode ceramah dimana peserta diberikan materi mengenai Harga Pokok Produksi. Dilanjutkan dengan metode tutorial dengam memberikan contoh ilustratif bagaimana melakukan penyusunan Laporan Harga Pokok Produksi yang benar. Kemudian diakhiri dengan diskusi dengan peserta.

\section{HASIL DAN PEMBAHASAN}

Pada saat sesi penyampaian materi, narasumber menyajikan pemaparan materi mengenai perhitungan harga pokok produksi kepada para pegiat usaha atau warga di desa Kota Kerinjing yang memiliki usaha kecil dan menengah. Paparan difasilitasi oleh in fokus dan print out power point yang dibagikan kepada para peserta agar dapat memahami materi secara utuh. Paparan menyajikan pengertian biaya, jenis-jenis biaya, dan cara perhitungan penetapan harga pokok produksi beserta contohnya. Sesi terakhir adalah sesi diskusi. Ada beberapa pertanyaan yang ditanyakan oleh para peserta berkaitan dengan perhitungan harga pokok produksi. Pertanyaan pertama diajukan oleh Bapak M. Nusantara selaku salah satu pegiat usaha di desa Kerinjing, pertanyaannya adalah apa yang dimaksud dengan biaya tenaga kerja tidak langsung dan bagaimana membedakan antara biaya tenaga kerja langsung dan biaya tenaga kerja tidak langsung beserta contohnya. Pertanyaan kedua diajukan oleh Bapak Solihin. Apakah menetapkan dan menghitung harga pokok produksi itu adalah hal yang wajib dan kenapa kita harus menghitung harga pokok produksi?.

Jawaban atas pertanyaan pertama adalah tenaga kerja adalah daya kerja fisik maupun mental yang merupakan sumbangsih menusia untuk menghasilkan suatu produk atau jasa tertentu. Tenaga kerja merupakan satu elemen terpenting dalam setiap perusahaan atau entitas usaha. Suatu produk tidak akan tercipta tanpa adanya salah satu faktor produksi ini. Oleh karena itu, keberadaan tenaga kerja sangatlah vital dalam sebuah perusahaan manufaktur maupun perusahaan jasa. Tenaga kerja perusahaan yang telah mengabdikan dirinya pada perusahaan tertentu tentunya akan mendapatkan imbalan berupa gaji atau upah yang sesuai dengan kinerja dan prestasi masing-masing tenaga kerja.. Tenaga kerja langsung pada prinsipnya terbatas pada tenaga kerja di pabrik yang secara langsung terlibat pada proses produksi dan biayanya dikaitkan 
pada biaya produksi atau pada barang yang dihasilkan. Sedangkan tenaga kerja tak langsung pengertiannya terbatas pada tenaga kerja di pabrik yang tidak terlibat secara langsung pada proses produksi dan biayanya dikaitkan pada biaya overhead pabrik.

Anggaran upah tenaga kerja langsung ialah anggaran yang merencanakan secaralebih terperinci tentang upah yang akan dibayarkan kepada para tenaga kerja langsungselama periode yang akan datang, yang didalamnya meliputi rencana tentang jumlahwaktu yang diperlukan oleh para tenaga kerja langsung untuk menyelesaikan unit yangakan diproduksikan, tarif upah yang akan dibayarkan kepada para tenaga kerja langsungdan kapan waktunya para tenaga kerja langsung menjalankan kegiatan prose produksi,yang masing-masing dikaitkan dengan jenis barang jadi(produk) yang akan dihasilkan,serta tempat atau departemen dimana para tenaga kerja langsung tersebut akan bekerja.Tenaga kerja langsung mempunyai sifat-sifat:1.Besar kacilnya biaya untuk tenaga kerja jenis ini berhubungan secara langsungdengan tingkat kegiatan produksi.2.Biaya yang dikeluarkan untuk tenaga kerja jenis ini merupakan biaya variabel.

Jawaban atas pertanyaan kedua adalah Harga pokok produksi adalah semua biaya langsung dan tidak langsung yang dikeluarkan perusahaan untuk proses produksi sehingga barang atau jasa tersebut bisa dijual. Perusahaan harus menghitung harga pokok suatu barang karena sangat penting untuk pelaporan keuangan perusahaan. Penentuan harga pokok produksi dilakukan sebelum perusahaan menentukan harga jual. Harga ini nantinya akan digunakan oleh manajemen untuk membandingkan dengan pendapatan dan disajikan dalam laporan laba rugi. Selain itu, perusahaan juga akan lebih mudah melakukan pengontrolan produksi jika mengetahui harga pokoknya.

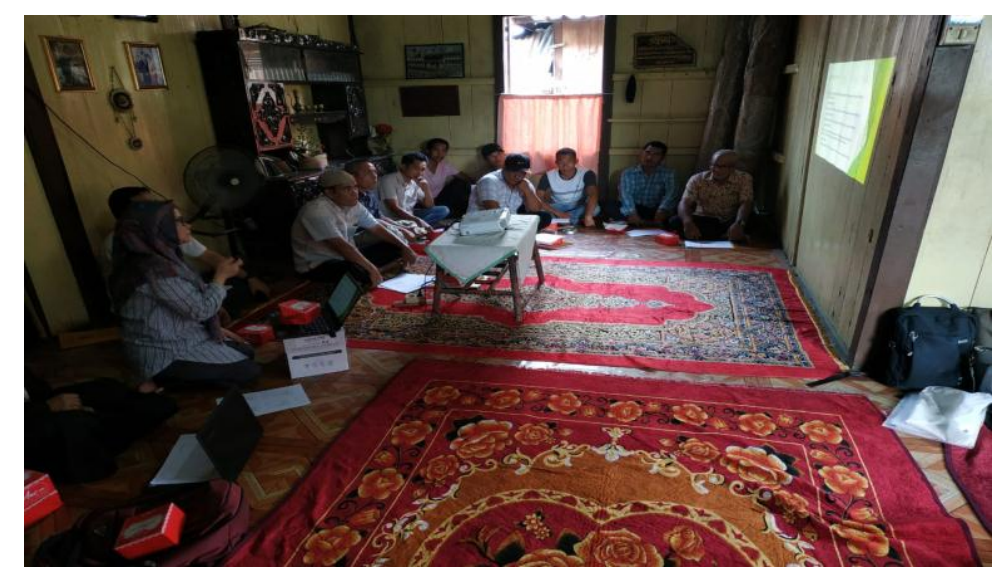

Gambar 1. penyampaian materi oleh bu yusnaini

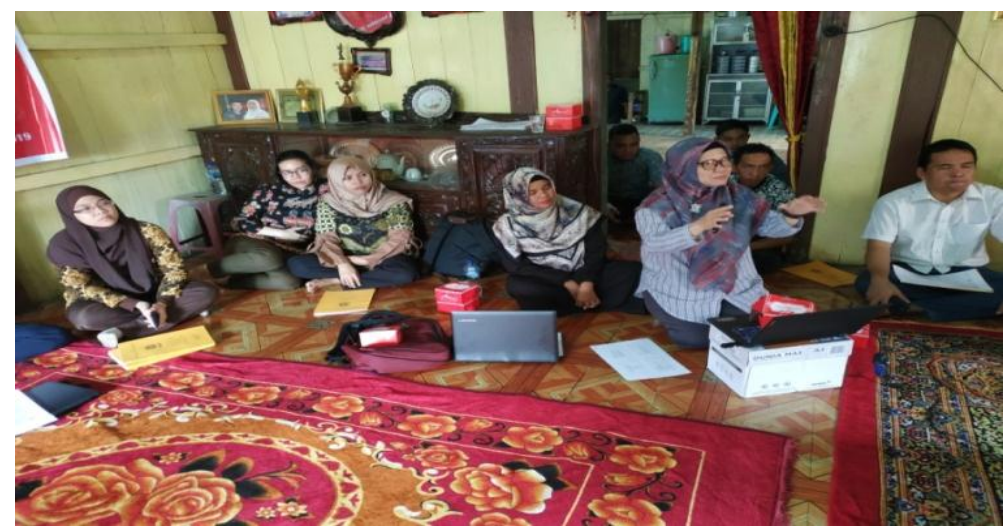

Gambar 2. Narasumber (Bu Yusnaini) sedang menjawab pertanyaan warga 


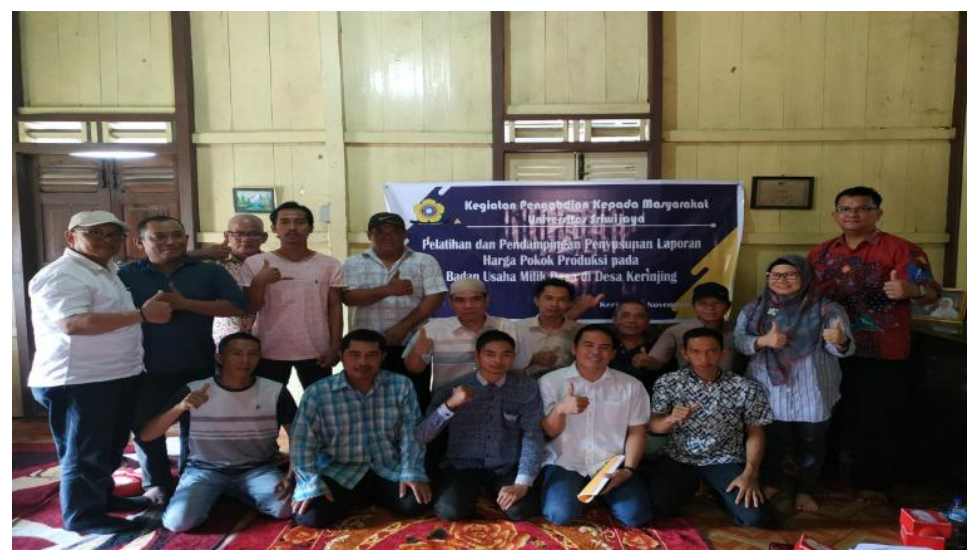

Gambar 3. Foto bersama warga

\section{SIMPULAN}

Hasil pelaksanaan kegiatan pengabdian kepada masyarakat ini dapat disimpulkan bahwa Peran aparat desa di Desa Kerinjing kecamatan Tanjung Raja Ogan Ilir berkaitan dengan penetapan dan perhitungan harga pokok produksi sangat besar. Dalam pelaksanaan pengabdian ini ada beberapa pertanyaan berkaitan dengan perhitungan harga pokok produksi yang harus dilakukan oleh pegiat usaha. Dengan demikian dalam pelaksanaan pengabdian ini mereka aktif berdiskusi berkaitan dengan menghitung harga pokok produksi. Perlu adanya pendampingan bagi aparat desa dalam menetapkan, menghitung, memperhitungkan berkaitan dengan harga pokok produksi.

\section{UCAPAN TERIMA KASIH}

Terima kasih kami ucapkan kepada pihak Fakultas Ekonomi Universitas Sriwijaya atas dana Pengabdian Kepada Masyarakat Tahun 2019 yang telah dianggarkan, dan Kepala Desa Kota Kerinjing Bapak Faisal Kimi dan seluruh peserta kegiatan pengabdian kepada masyarakat Tahun 2019.

\section{REFERENSI}

Budiman, A, I., Siregar, M, I., Samantha, R., Khamisah, N., Listya, A., \& Pratiwi, T, S. (2020). Sosialiasi dan Pelatihan Penyusunan Laporan Keuangan UMKM di Desa Kerinjing Kecamatan Tanjung Raja Kabupaten Ogan Ilir Sumatera Selatan. Jurnal Abdimas Mandiri, Vol. 4, No. 1.

Carter, K, W. (2009). Akuntansi Biaya. Buku 1. Edisi Keempat Belas, Jakarta: Salemba Empat.

Mulyadi. (2007). Akuntansi Biaya. Yogyakarta. YKPN.

Mulyadi. (2010). Akuntansi Manajemen: Konsep, Manfaat dan Rekayasa. Edisi 3. Salemba Empat, Jakarta.

Peraturan Menteri Dalam Negeri Nomor 113 Tahun 2014 Tentang Pengelolaan Keuangan Desa.

Peraturan Pemerintah Nomor 43 Tahun 2014 Tentang Desa.

Peraturan pemerintah No 43 tahun 2014 Tentang Peraturan Pelaksanaan Undang-Undang Nomor 6 tahun 2014 Mengenai Dana Desa.

Peraturan Menteri Desa Nomor 3 Tahun 2015 Tentang Pendampingan Desa.

Undang-Undang Nomor 6 Tahun 2014 Tentang Desa.

Undang-Undang Nomor 23 Tahun 2014 Tentang Pemerintah Daerah.

Undang-Undang Nomor 12 Tahun 2008 Perubahan atas Undang-Undang Nomor 32 tahun 2004 tentang Pemerintahan Daerah. 